Research article

\title{
THE EFFECT OF CARVACROL ON INFLAMMATORY PAIN AND MOTOR COORDINATION IN RATS
}

\author{
MILOVANOVIĆ Mirjana ${ }^{1 *}$, MLOSAVLJEVIĆ Miloš ${ }^{1}$, MARJANOVIĆ S Đorđe ${ }^{1}$, \\ TRAILOVIĆ M Saša ${ }^{1}$, VUČINIĆ Marijana ${ }^{1}$, NEDELJKOVIĆ TRAILOVIĆ Jelena ${ }^{1}$, \\ MARKOVIĆ Maja ${ }^{1}$, ĐURĐEVIĆ Dragan ${ }^{2}$
}

${ }^{1}$ Faculty of Veterinary Medicine University of Belgrade, Bul. Oslobodjenja 18, 11000 Belgrade, Serbia. ${ }^{2}$ Military Medical Academy, Crnotravska 17, 11000 Belgrade, Serbia

(Received 31 May; Accepted 18 October 2016)

\begin{abstract}
Carvacrol is a monoterpenic phenol and an active ingredient of the plant essential oils of the family Lamiaceae. We have investigated the analgesic effect of carvacrol, the possible dependence of the effect in relation to animal sex, and the impact of carvacrol on motor coordination in rats. Hyperalgesia was induced by formalin $(1.5 \%)$, which was administered SC in the upper lip of rat. Hyperalgesia and effects of carvacrol and indomethacin were measured by using the orofacial formalin test. The influence on motor coordination in animals treated with carvacrol was investigated by using the rota-rod test. Carvacrol administered PO in pre-treatment (45 min. prior to formalin) at a single dose of 50, 75 and $100 \mathrm{mg} / \mathrm{kg} \mathrm{BW}$, in the male, 50 and $100 \mathrm{mg} / \mathrm{kg} \mathrm{BW}$, in female rats caused a dose-dependent antinociceptive effect. This effect of carvacrol was significantly higher $(\mathrm{P}<0.01, \mathrm{P}<0.001)$ in male rats. Compared with indomethacin administered during pre-treatment $(2 \mathrm{mg} / \mathrm{kg}$, PO), carvacrol $(100 \mathrm{mg} / \mathrm{kg})$ exhibits significantly higher $(\mathrm{P}<0.05$ and $\mathrm{P}<0.001)$ antinociceptive effect on formalininduced hyperalgesia in male rats. In the rota-rod test carvacrol did not disturb the motor coordination in male rats, nor the dose of carvacrol with clear antinociceptive properties exhibited depressive effect on the CNS of treated rats. Keeping in mind that the monoterpene carvacrol is of plant origin, with potentially less side effects and without residues, it is realistic to expect the possibility of its therapeutic use in the treatment of inflammatory pain in animals.
\end{abstract}

Key words: Carvacrol, indomethacin, nociception, motor coordination, rat.

\section{INTRODUCTION}

Carvacrol (5-isopropyl-2methylphenol) is the monoterpene phenol. Together with other monoterpenes (thymol, $p$-cymene, limonene, $\alpha$-terpinene), carvacrol is present in the essential oils of plants from the Lamiaceae family (1). The genus Thymus contains about 350 species, of which the most commonly are Thymus serpyllum and Thymus

\footnotetext{
*Corresponding author: e-mail: miram@vet.bg.ac.rs
} 
vulgaris, Oregano (Origanum vulgare) and Winter Savory (Satureja Montana). All of these species contain a high concentration of monoterpenes, and are used in the traditional medicine of many different cultures for the treatment of diseases of the respiratory and digestive tract (2). So far, research into the pharmacological properties of carvacrol showed that it possesses antimicrobial [1, 2], antiparasitic [3, 7], anti-inflammatory [5], cytostatic [6], analgesic [4] and antispasmodic effects [8]. Also, it was shown that carvacrol acts as an antioxidant, hypoglycemic and cholesterol lowering agent $[8,9]$.

In addition to the well proven anti-inflammatory effects of carvacrol [10], recently, the researchers have become increasingly interested in the study of analgesic action of this monoterpene. It has been shown that carvacrol administered orally in mice reduces formalin-induced nociception, mechanical hyperalgesia and inflammation in damaged tissues [11]. Also, Guimaraes et al [12] demonstrated that carvacrol administered orally in mice exhibits significant antinociceptive and anti-edematous activity on hyperalgesia and edema caused by carrageenan and tumor necrosis factor-alpha (TNF- $\alpha$ ). However, carvacrol exhibits no effect on the hyperalgesia induced by prostaglandin E2 (PGE2) and dopamine. Proven antinociceptive activity have other monoterpenes, such as $p$-cymene and geranyl acetate [13]. Similarly, the essential oil of rosemary (Rosmarinus officinalis) comprising predominant 1.8-cineole, camphor and $\alpha$-pinene [14], exhibits a significant antinociceptive effect in the acetic acid-induced writhing test in mice [15].

The above studies clearly indicate the analgesic potential of carvacrol, and the fact that this monoterpene is of vegetable origin, its possible application in the pharmacotherapy of pain (fewer side effects). These data directed our study on the investigations of carvacrol analgesic properties in the model of inflammatory pain.

The aim of this study was to investigate the antinociceptive effect of carvacrol in the model of inflammatory pain and the impact of carvacrol on motor coordination in male and female rats.

\section{MATERIALS AND METHODS}

\section{Ethical approval}

All experimental procedures where performed with the permission of the Ministry of Agriculture, Forestry and Water Management of the Republic of Serbia-Veterinary Directorate (permit No323-07-05566/20I5 -05/1).

\section{Animals}

Adult male Wistar rats (180-220g) used in the present study were taken from the Military Academy Breeding Farm, Belgrade, Serbia. The animals were housed in groups of four in home cages $(42.5 \times 27 \times 19 \mathrm{~cm})$ under standard conditions: temperature of $21 \pm 1^{\circ} \mathrm{C}$, relative humidity of $55-60 \%$ and $12 / 12 \mathrm{~h}$ light/dark cycle. Food and water were provided ad libitum, except during the experimental procedure. 
The animals were habituated individually in a Plexiglass chamber for 30 min before testing. All behavioural testing was done between 9:00 A.M. and 2:00 P.M.

For each tested dose of the test substances (carvacrol, indomethacin), as well as for the controls (absolute control=purified water; vehicle-control=ethanol-aqueous solvent), were formed groups of 6 rats each.

\section{Drugs and administration}

Substances used in this study were: formalin (Zorka Pharma), carvacrol (SigmaAldrich), indomethacin (Sigma-Aldrich), absolute ethanol (Zorka Pharma), saline (Hemofarm), and purified water (Aq. purif.). Concentrated formalin (35\%) was diluted with saline, carvacrol with ethanol-aqueous solvent, and indomethacin was dissolved in the ethanol-aqueous solvent. Absolute control group of rats was treated orally (PO) with purified water, while vehicle-control group was treated orally with ethanol-aqueous solvent. Other groups of rats were treated orally with carvacrol or indomethacin. Oral administration was performed using a gastric tube. Volume of carvacrol, indomethacin or vehicle did not exceed $0.1 \mathrm{ml} / 100 \mathrm{~g}$ body weight (BW).

\section{Experimental methods}

\section{The orofacial formalin test}

To determine the severity of inflammatory pain (nociception), the orofacial formalin test was applied. The test is intended for assessing the intensity of nociception caused by subcutaneous (SC) injection of formalin $(1.5 \%, 0.1 \mathrm{ml}$ ) in rats upper lip (about 3-5 mm lateral to the nasal openings). Formalin injection causes inflammation and nociception which expresses the energy, fast rubbing perinasal region (upper lip, nose) ipsilateral front or rear paw, or both front paws. This response is biphasic. First, acute (nociceptive) phase begins immediately after application of a formalin solution and lasts for 3-5 minutes. Then follows the grace period (10-15 min). Second, tonic (inflammatory) phase begins after the end of the grace period and lasts 20-40 minutes. The parameter that was measured was the time expressed in seconds (s) that a rat spends in nociceptive behaviour. In experiments the recording time is generally divided into 15 blocks of 3 min for a time course analysis [16].

\section{Rota-rod motor coordination test}

For testing the possible impact of carvacrol on the motor coordination in the rats "Rota-rod" test was used. This test measured the ability of the rat to preserve balance holding itself on the rotating rod.

Motor performance was assessed by means of an automated Rota-rod and software and database developed by El Unit, Belgrade, Serbia. Before the beginning of the sessions, all animals were allowed to habituate with the apparatus during 1 min with 
no rotation and for $5 \mathrm{~min}$ with a low speed rotation $(4 \mathrm{rpm})$. Then, the speed of the rotation increased from 4 to $15 \mathrm{rpm}$ (during $5 \mathrm{~min}$ ). The test was performed on welltrained two groups per 6 rats. One is the vehicle-control group and the second is the carvacrol treated group. The effect of the maximal dose of carvacrol $(100 \mathrm{mg} / \mathrm{kg})$ on the integrity of motor coordination was assessed based on the ability of rats to stay on a rotated rod for $5 \mathrm{~min}$ without falling for $0,45,90$ and $180 \mathrm{~min}$ after drug administration. The rats were trained during 5 days before the application of carvacrol to obtain an optimal level of performances, and the performances of the last day were used as the reference value [17].

Righting reflex and tail pinch test were used to determine possible clinical visible general depressive effects of the applied carvacrol on the rats CNS. A positive tail-pinch response was considered to be a movement of the body on a flat surface in response to a pinch of the tail by forceps. The righting reflex was considered normal when the rat could right itself from a prone position. All tests were conducted immediately after the application of drug and before placing it on the rotating rod [17].

\section{Statistical analysis}

The data were statistically analysed by linear regression, One-Way Analysis of Variance (ANOVA) and the post hoc Tukey`s HSD test for multiple comparisons. A level of $P<0.05$ was considered statistically significant.

\section{RESULTS}

\section{Examination of antinociceptive effect of carvacrol in male and female rats}

Carvacrol administered PO in the increasing doses of 50, 75 and $100 \mathrm{mg} / \mathrm{kg}, 45$ minutes before formalin injection $(1.5 \% ; 0.1 \mathrm{ml})$, produced a significant dosedependent antinociceptive effect $(\mathrm{p}<0.05, \mathrm{p}<0.01, \mathrm{p}<0.001)$ in male rats. A significant antinociceptive effect of carvacrol was observed with the two higher tested doses (75 and $100 \mathrm{mg} / \mathrm{kg}$ ), and at both phases the formalin-induced nociception. Carvacrol administered in the lowest dose of $50 \mathrm{mg} / \mathrm{kg}$, achieved an antinociceptive effect in the first phase of the formalin-induced nociception, in the time interval of 3-6 minutes, as well as in the final part of the second tonic phase of the formalin-induced nociception. Those effects of carvacrol exhibited minimal statistical significance (Fig.1). Dose-dependence of the antinociceptive effect of carvacrol was confirmed by the constructed regression lines for both phases of nociception induced by formalin (Fig.2).

Carvacrol administered PO in the higher dose $(100 \mathrm{mg} / \mathrm{kg})$ to female rats 45 minutes prior application of formalin $(1.5 \%, 0.1 \mathrm{ml}, \mathrm{SC})$ caused a significant reduction $(\mathrm{p}<0.05$, $\mathrm{p}<0.01, \mathrm{p}<0.001)$ in the formalin-induced nociception (both phases). On the other hand, the lower dose $(50 \mathrm{mg} / \mathrm{kg}$ ) of carvacrol had an insignificant effect on the nociception induced by formalin (Fig. 3). 

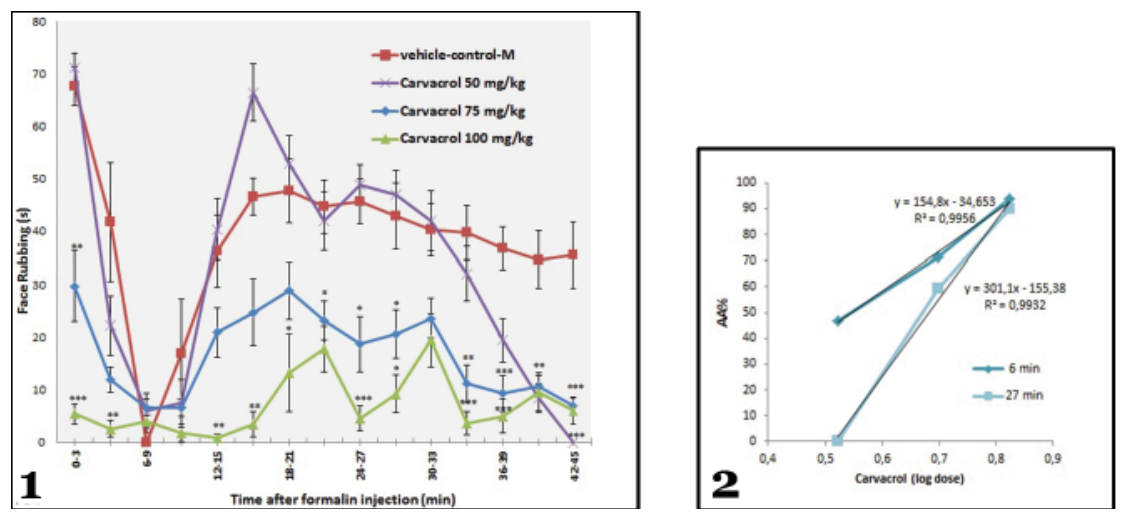

Figure 1. Antinociceptive effect of carvacrol $(50,75,100 \mathrm{mg} / \mathrm{kg})$ on the formalin-induced nociception in male rats. Carvacrol was administered PO, 45 min before formalin $(1.5 \%, 0.1$ $\mathrm{ml}, \mathrm{SC})$. The symbols denote mean \pm SEM of 6 rats per group. $* \mathrm{P}<0.05, * * \mathrm{P}<0.01$ and $* * * \mathrm{P}<0.01$ vs. vehicle-control-M, one-way ANOVA followed by post hoc Tukey`s HSD test.

Figure 2. The regression lines of the antinociceptive effect of carvacrol $(50,75,100 \mathrm{mg} / \mathrm{kg}$, PO) at 6 min (first phase) and $27 \mathrm{~min}$ (second phase) on the formalin-induced nociception in the orofacial formalin test in male rats $(n=6)$. \%AA- percent antinociceptive activity was calculated according to the following formula: $\% \mathrm{AA}=$ (vehicle-control group average face rubbing $(\mathrm{s})$ - test group average face rubbing $(\mathrm{s})$ ) / (vehicle-control group average face rubbing (s)) x $100(18)$.

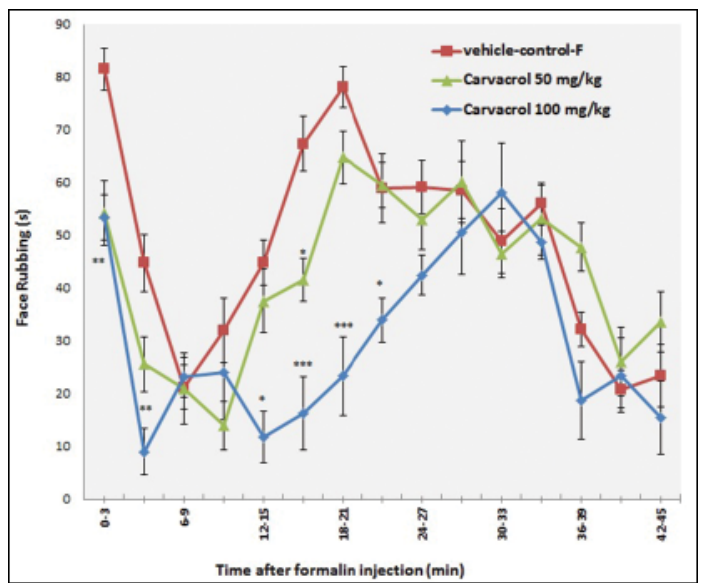

Figure 3. Antinociceptive effect of carvacrol $(50$ and $100 \mathrm{mg} / \mathrm{kg}$ ) on the formalin-induced nociception in female rats. Carvacrol was administered PO, 45 min before formalin $(1.5 \%$, $0.1 \mathrm{ml}, \mathrm{SC})$. The symbols denote mean \pm SEM of 6 rats per group. $* \mathrm{P}<0.05, * * \mathrm{P}<0.01$ and $* * * \mathrm{P}<0.01$ vs. vehicle-control-F, one-way ANOVA followed by post hoc Tukey`s HSD test.

The ethanol-aqueous solvent $(0.1 \mathrm{ml}, \mathrm{PO})$ used for the dilution of carvacrol, did not affect the nociception caused by formalin in male and female rats (Fig.4A, B). 

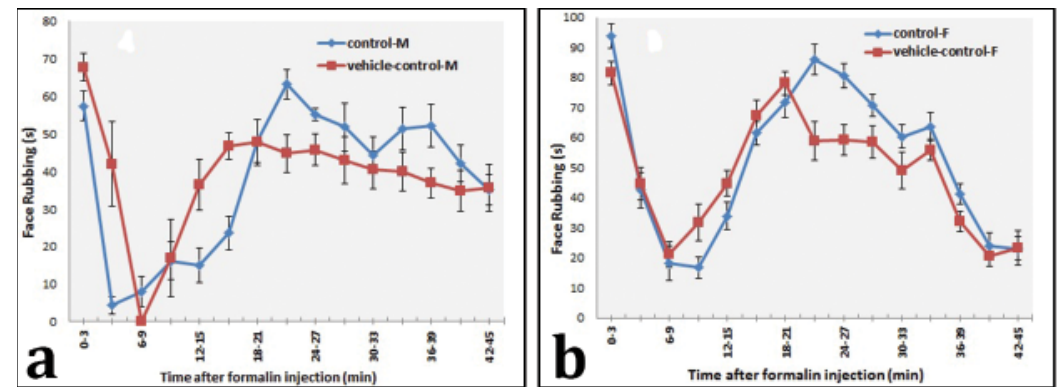

Figure 4. Nociception of the perinasal region of rats was induced by formalin $(1.5 \%, 0.1 \mathrm{ml}$, SC) in male (A) and female (B) rats. Control-M and control-F were treated orally with purified water $(0.1 \mathrm{ml})$, and the vehicle-control-M and vehicle-control-F were treated orally with ethanol-aqueous solvent $(0.1 \mathrm{ml}) 45$ minutes prior to formalin $(\mathrm{n}=6)$.

\section{Examination of differences in antinociceptive effect of carvacrol in relation to the sex of rats}

In male and female rats carvacrol causes qualitatively the same antinociceptive effect on formalin-induced nociception of the perinasal region. By comparing the intensity of antinociceptive effects of carvacrol applied at a dose of $100 \mathrm{mg} / \mathrm{kg}$ in male and female rats, can be seen that this monoterpene achieved a significantly greater antinociceptive effect $(\mathrm{p}<0.01, \mathrm{p}<0.001)$ in male rats (Fig. 5). Also, by comparing the intensity of formalin-induced nociception in the orofacial formalin test in relation to the sex of the animals, it is noticeable that the male rats are slightly less sensitive than females, but without statistical significance (Fig. 6).
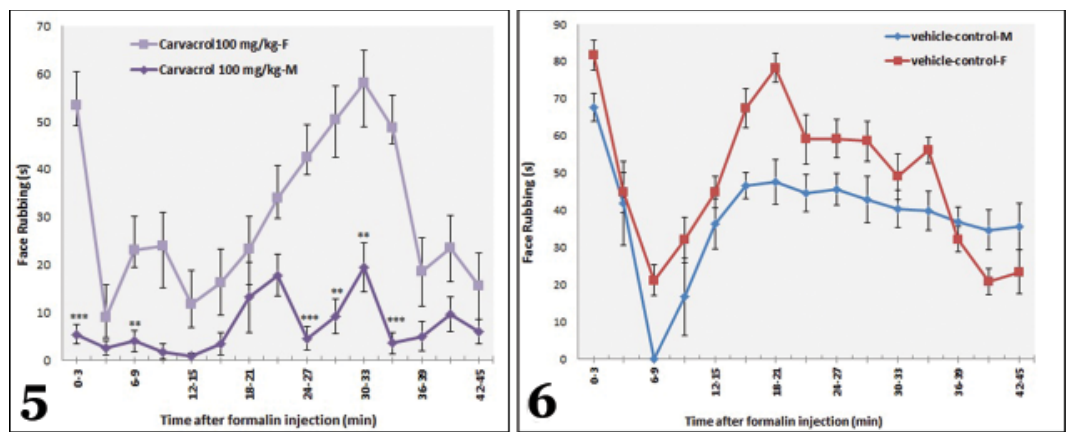

Figure 5. Comparison of the antinociceptive effect of carvacrol $(100 \mathrm{mg} / \mathrm{kg})$ on nociception induced by formalin in male and female rats. Carvacrol was administered PO, 45 min before formalin $(1.5 \%, 0.1 \mathrm{ml}, \mathrm{SC})$. The symbols denote mean \pm SEM of 6 rats/group. ${ }^{* *} \mathrm{P}<0.01$ and $* * * \mathrm{P}<0.01$ vs. vehicle-control-F, one-way ANOVA followed by post hoc Tukey`s HSD test.

Figure 6. Comparison of the nociception of perinasal region of the rats was induced by formalin $(1.5 \%, 0.1 \mathrm{ml}, \mathrm{SC})$ in male and female rats. Vehicle-control-M and vehicle-control-F were treated PO with ethanol-aqueous solvent $(0.1 \mathrm{ml}), 45 \mathrm{~min}$ prior to formalin $(\mathrm{n}=6)$. 


\section{Comparative study of the antinociceptive effects of carvacrol and indomethacin in male rats}

Indomethacin administered at a dose of $2 \mathrm{mg} / \mathrm{kg}$, PO 45 minutes prior to the application of formalin $(1.5 \%, 0.1 \mathrm{ml})$, in the male rats causes a slight reduction of the nociception induced by formalin. Comparing the antinociceptive effect of carvacrol $(100 \mathrm{mg} /$ $\mathrm{kg})$ and indomethacin $(2 \mathrm{mg} / \mathrm{kg})$ in male rats it is evident that carvacrol achieves a significantly higher antinociceptive effect on the formalin-induced nociception, than analgoantipyretic indomethacin administered at the recommended dose (Fig.7).

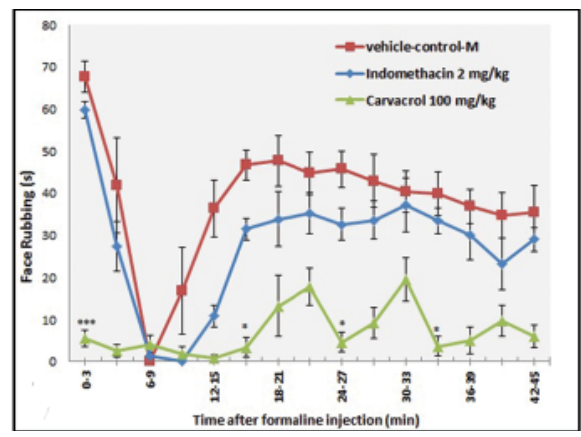

Figure 7. Comparison of the antinociceptive effects of carvacrol $(100 \mathrm{mg} / \mathrm{kg})$ and indomethacin $(2 \mathrm{mg} / \mathrm{kg})$ on nociception induced by formalin in male rats. Carvacrol and indomethacin were administered PO, 45 min before formalin $(1.5 \%, 0.1 \mathrm{ml}, \mathrm{SC})$. The symbols denote mean \pm SEM of 6 rats/group. $* \mathrm{P}<0.05$ and $* * * \mathrm{P}<0.01$ vs. Indomethacin $2 \mathrm{mg} / \mathrm{kg}$, one-way ANOVA followed by post hoc Tukey`s HSD test.

\section{Effect of carvacrol on motor cordination in male rats}

Male rats treated with ethanol-aqueous solvent $(0,1 \mathrm{ml} / 100 \mathrm{~g} \mathrm{BW})$ (vehicle-control group, $n=6)$ did not fall off the rotating rod for $0,45,90$ and $180 \mathrm{~min}$ after vehicle administration. Also, the male rats treated with carvacrol at the maximal dose of $100 \mathrm{mg} / \mathrm{kg}$ did not show disturbances of motor coordination in any time point of measurement (Tab.1). All tested rats did not display visible signs of CNS depression, righting reflex was fully preserved and walking on a flat static surface (after tail pinch test) was normal.

Table 1. Effect of carvacrol $(100 \mathrm{mg} / \mathrm{kg})$ on motor coordination of rats $(\mathrm{n}=6)$ in the rota-rod test performed 45, 90 and 180 min after oral administration.

\begin{tabular}{cccc}
\hline \multirow{2}{*}{$\begin{array}{c}\text { Number of rats fallen before } \\
\text { administration of carvacrol }\end{array}$} & \multicolumn{2}{c}{ Number of rats fallen after administration of carvacrol } \\
\cline { 2 - 4 } & $\mathbf{4 5} \mathbf{m i n}$ & $\mathbf{9 0} \mathbf{m i n}$ & $\mathbf{1 8 0} \mathbf{m i n}$ \\
\hline $0 / 6$ & $0 / 6$ & $0 / 6$ & $0 / 6$ \\
\hline
\end{tabular}




\section{DISCUSSION}

In the present study carried out on Wistar rats of both sexes, carvacrol administered orally in pre-treatment of formalin-induced hyperalgesia achieved a dose-dependent analgesic effect. The results of this experiment are matched with the results published by Santana et al. These authors have achieved an antinociceptive effect of carvacrolpropionate when this derivate of monoterpene administered to mice orally in the same dosage range $(25,50,100 \mathrm{mg} / \mathrm{kg})$ in the pre-treatment of hyperalgesia caused by formalin [11]. Also, Bonfit et al showed that isoproxy-carvacrol administered intraperitoneally $(10,30,100 \mathrm{mg} / \mathrm{kg})$ in the pre-treatment of formalin-induced hyperalgesia in mice and in the pre-treatment of carrageenan-induced hyperalgesia in rats (paw pressure tests), achieved a significant antinociceptive effect only at the highest dose $(100 \mathrm{mg} / \mathrm{kg})$ [19]. Dose-dependent antinociceptive effect of carvacrol was confirmed using this monoterpene in other analgesic tests, such as acetic acidinduced writhing test and "hot-plate" test in mice [4].

In the next part of our investigation we were interested to examine whether a difference in the analgesic effect of carvacrol exists with respect to the sex in rats. Thus, we have shown that the analgesic activity of carvacrol $(100 \mathrm{mg} / \mathrm{kg})$ is affected by sex, but response to formalin is not significantly influenced by sex. However, in comparison with females, slightly less sensitivity of males to the development of formalin hyperalgesia might be responsible, at least partially for their higher sensitivity to the effect of carvacrol administered in the highest dose of $100 \mathrm{mg} / \mathrm{kg}$.

In the continuation of our research we compared the antinociceptive effect of carvacrol on formalin-induced nociception with the antinociceptive effect of standard analgoantipyretic indomethacin. Thus, carvacrol administered orally $(100 \mathrm{mg} / \mathrm{kg}$ ) in male rats exhibited a significantly higher antinociceptive effect than indomethacin administered in the same way in the therapeutic dose $(2 \mathrm{mg} / \mathrm{kg})$. Analgesic activity of carvacrol $(100 \mathrm{mg} / \mathrm{kg})$ and indomethacin $(5 \mathrm{mg} / \mathrm{kg}$ ) in male mice was compared by Cavalcante Melo et al. These authors have observed the same coincidence of intensity in antinociceptive effects, which is in accordance with 2.5-fold higher dose of indomethacin administered in formalin test in mice [4].

In the process of developing a new analgesic it is important to examine the impact of the potential drug on the coordination of movement, as well as the potential depressive effect on the CNS. In our study, carvacrol applied in the maximal tested dose of $100 \mathrm{mg} / \mathrm{kg}$, did not disturb motor coordination in rats, and the applied dose did not produces visible clinical depression of the CNS. Similarly, the spontaneous locomotor activity of mice exposed to carvacrol $(100 \mathrm{mg} / \mathrm{kg}$, IP) was not affected in the experiments performed by Guimarăes et al. [12]. If it is known that the oral $\mathrm{LD}_{50}$ of carvacrol in the rat is $810 \mathrm{mg} / \mathrm{kg} \mathrm{BW}$, and that the major toxic effects of monoterpenes are related to the disorder of CNS (20), it was expected that carvacrol in the highest tested dose $(100 \mathrm{mg} / \mathrm{kg})$ in our experiments is not able to alter the motor coordination in rats. 


\section{CONCLUSION}

In the present study carried out on rats of both sexes is shown that: 1) carvacrol administered orally during pre-treatment on formalin-induced nociception achieves a dose-dependent antinociceptive effect in rats. 2) The analgesic activity of carvacrol in relation to the sex is the same in quality, but is different in quantity. This means that in male rats antinociceptive effect of carvacrol on formalin-induced nociception is significantly higher than in females. 3) Comparing the antinociceptive effect of carvacrol and standard analgoantipyretic indomethacin on formalin-induced nociception in male rats is shown that carvacrol administered orally at the highest examined dose achieves a significantly higher antinociceptive effect than indomethacin applied in the therapeutic dose. 4) Carvacrol does not affect the spontaneous locomotor activity and motor coordination in rats.

Bearing in mind the presented conclusions and the fact that carvacrol is a monoterpene of plant origin, with potentially less side effects and without residue, it is realistic to expect the possibility of its therapeutic use in the regulation of inflammatory pain in animals.

\section{Acknowledgments}

This work was conceived and financially supported as part of the project "Development of herbal medicines and biocides on the basis of carvacrol, thymol and cinnamaldehyde for use in veterinary medicine, animal husbandry and food production without harmful residues" (No TP 31087).

\section{Authors' contributions}

MMilovanović, MMilosavljević and ĐM were administered drugs and measured of nociception by vonFrey apparatus. ĐM and DĐ were implemented the rota-rod test. ST and JNT performed statistical analysis of data. MV has pursued ethical procedure. MMilovanović wrote the text of the article. MMarković wrote the English text of the article.

\section{Declaration of conflicting interests}

The author(s) declared no potential conflicts of interest with respect to the research, authorship, and/or publication of this article. 


\section{REFERENCES}

1. Sharifi-Rad J, Sharifi-Rad M, Hoseini-Alfatemi SM, Iriti M, Sharifi-Rad M, Sharifi-Rad M: Composition, cytotoxic and antimicrobial activities of Satureja intermedia C.A. Mey essential oil. Int J Mol Sci 2015, 16:17812-17825.

2. Nabavi SM, Marchese A, Izadi M, Curti V, Daglia M, Nabavi SF: Plants belonging to the genus Thymus as antibacterial agents: from farm to pharmacy. Food Chem 2015, 173:339347.

3. Grabensteiner E, Arshad N, Hess M: Differences in the in vitro susceptibility of monoeukaryotic cultures of Histomonas meleagridis, Tetratrichomonas gallinarum and Blastocystis sp. to natural organic compounds. Parasitol Res 2007, 101(1):193-199.

4. Cavalcante Melo FH, Rios ER, Rocha NF, Citó Mdo C, Fernandes ML, de Sousa DP, de Vasconcelos SM, de Sousa FC: Antinociceptive activity of carvacrol (5-isopropyl-2methylphenol) in mice. J Pharm Pharmacol 2012, 64(12):1722-1729.

5. Lima M da S, Quintans-Júnior LJ, de Santana WA, Martins Kaneto C, Pereira Soares MB, Villarreal CF: Anti-inflammatory effects of carvacrol: evidence for a key role of interleukin-10. Eur J Pharmacol 2013, 699:112-117.

6. Fan K, Li X, Cao Y, Qi H, Li L, Zhang Q, Sun H: Carvacrol inhibits proliferation and induces apoptosis in human colon cancer cells. Anticancer Drugs 2015, 26(8):813-823.

7. Trailović SM, Marjanović DS, Nedeljković Trailović J, Robertson AP, Martin RJ: Interaction of carvacrol with the Ascaris suum nicotinic acetylcholine receptors and gammaaminobutyric acid receptors, potential mechanism of antinematodal action. Parasitol Res 2015, 114(8):3059-3068.

8. Goze I, Alim A, Cetinus SA, Cetin A, Durmus N, Atas AT, Vural N: In vitro antimicrobial, antioxidant, and antispasmodic activities and the composition of the essential oil of Origanum acutidens (Hand.-Mazz.) Ietswaart. J Med Food 2010, 13(3):705-709.

9. Čapkovičová A, Maková Z, Piešová E, Alves A, Faix Š, Faixová Z: Evaluation of the effects of Saliva officinalis essential oil on plasma biochemistry, gut mucus and quantity of acidic and neutral mucins in the chicken gut. Acta Vet (Beograd) 2014, 46(1):138-148.

10. de Cássia da Silveira e Sá R, Andrade LN, de Sousa DP: A review on anti-inflammatory activity of monoterpenes. Molecules 2013, 18(1): 1227-1254.

11. de Santana M., Silva VB, de Brito RG, dos Santos PL, de Holanda Cavalcanti SC, Barreto EO, de Souza Ferro JN, dos Santos MR, de Sousa Araujo AA, Quintans -Junior LJ: Synthesis and pharmacological evaluation of carvacrol propionate. Inflammation 2014, 37(5):1575-1587.

12. Guimarăes AG, Xavier MA, de Santana MT, Camargo EA, Santos CA, Brito FA, Barreto EO, Cavalcanti SC, Antoniolli AR, Oliveira RC, Quintans-Junior, LJ: Carvacrol attenuates mechanical hypernociception and inflammatory response. Naunyn Schmiedebergs Arch Pharmacol 2012, 385(3):253-263.

13. Quintans-Júnior L, Moreira JC, Pasquali MA, Rabie SM, Pires AS, Schröder R, Rabelo TK, Santos JP, Lima PS, Cavalcanti SC, Araújo AA, Quintans JS, Gelain DP: Antinociceptive activity and redox profile of the monoterpenes (+)-Camphene, p-Cymene, and Geranyl Acetate in experimental models. ISRN Toxicol 2013, ID459530, 1-11.

14. Badreddine BS, Olfa E, Samir D, Hnia C, Lahbib BJ: Chemical composition of Rosmarinus and Lavandula essential oils and their insecticidal effects on Orgyia trigotephras (Lepidoptera, Lymantriidae). Asian Pac J Trop Med 2015, 8(2):98-103. 
15. Takaki I, Bersani-Amado LE, Vendruscolo A, Sartoretto SM, Diniz SP, Bersani-Amado CA, Cuman RK: Anti-inflammatory and antinociceptive effects of Rosmarinus officinalis L.essential oil in experimental animal models. J Med Food 2008, 11(4):741-746.

16. Raboisson P, Dallel R: The orofacial formalin test. Neurosci Biobehav Rev 2004, 28(2): 219-226.

17. Trailovic SM, Ivanovic SV, Varagic VM: Ivermectin effects on motor coordination and contractions of isolated rat diaphragm. Res Vet Sci 2011, 91(3): 426-433.

18. Milovanović M, Vučković S, Prostran M, Trailović S, Jovanović M: L-arginine-NO system participates in the analgesic effect of flunixin meglumine in the rat. Acta Vet Beograd, 2016, 66(1):103-114.

19. Bonfim RR, Paiva-Souza IO, Moraes JP, Pereira DS, Santos CA, Santana DG, Thomazzi SM, Ferro JN, Barreto EO, Sousa DP, Camargo EA: Isopropoxy-carvacrol, a derivative obtained from carvacrol, reduces acute inflammation and nociception in rodents. Basic Clin Pharmacol Toxicol 2014, 115(3):237-243.

20. Tisserand R, Young R.: Chapter 3-Toxicity. In: Essential Oil Safety: A Guide for Health Care Professionals, 2nd ed. Churchil Livingstone Elsevier, 2014, 25-30.

\title{
UTICAJ KARVAKROLA NA INFLAMATORNI BOL I KOORDINACIJU KRETANJA KOD PACOVA
}

\author{
MILOVANOVIĆ Mirjana, MILOSAVLJEVIĆ Miloš, MARJANOVIĆ S Đorđe, \\ TRAILOVIĆ M Saša, VUČINIĆ Marijana, NEDELJKOVIĆ TRAILOVIĆ Jelena, \\ MARKOVIĆ Maja, ĐURĐEVIĆ Dragan
}

Karvakrol je monoterpenski fenol i sastavni je deo esencijalnih ulja biljaka iz familije Lamiaceae. Cilj ovog istraživanja bio je da se ispita analgetičko dejstvo karvakrola, moguće razlike u farmakološkom odgovoru između polova, i uticaj karvakrola na koordinaciju kretanja kod pacova. Hiperalgezija je izazvana formalinom (1,5\%) koji je aplikovan s.c. u gornju usnu pacova. Hiperalgezija i efekti karvakrola i indometacina mereni su orofacijalnim formalinskim testom. Uticaj na motornu koordinaciju kod životinja tretiranih karvakrolom ispitali smo rota-rod testom. Karvakrol primenjen p.o. u pretretmanu (45 min. pre aplikacije formalina) u dozi od 50, 75 i $100 \mathrm{mg} / \mathrm{kg} \mathrm{t.m.} \mathrm{kod}$ mužjaka i dozi od 50 i $100 \mathrm{mg} / \mathrm{kg}$ t.m. kod ženki pacova, prouzrokuje dozno zavisan antinociceptivni efekat. Ovaj efekat karvakrola je značajno veći $(\mathrm{P}<0,01, \mathrm{P}<0,001)$ kod pacova muškog pola. U poređenju sa indometacinom aplikovanim u pretretmanu (2 mg/kg, p.o.), karvakrol (100 mg/kg) ispoljava značajno veći $(\mathrm{P}<0,05$ i $\mathrm{P}<0,001)$ antinociceptivni efekat na formalinom izazvanu hiperalgeziju kod mužjaka pacova. U rota-rod testu karvakrol nije narušio motornu koordinaciju kod mužjka pacova, niti doza karvakrol sa jasnim antinociceptivnim svojstvima deluje depresivno na CNS tretiranih pacova. Imajući u vidu da je karvakrol monoterpen biljnog porekla sa malo potencijalnih neželjenih dejstava i bez rezidua, realno je očekivati mogućnost njegove primenu u terapiji inflamatornog bola kod životinja. 